Під час кризи та ізоляції роль мистецтва стає більш важливою в нашому житті - незалежно від того, усвідомлюємо ми це чи ні. «Об'єднання людей, натхнення, заспокоєння і спільне використання - це сили мистецтва, значення яких стало очевидним під час пандемії COVID-19», - заявила Одрі Азулай, генеральний директор ЮНЕСКО, в одному зі своїх весняних звернень.

I якщо протягом строгого карантину мистецтво виконувало в основному терапевтичну функцію як для самих художників, так і для їх аудиторії, то зараз, коли спостерігається спад інтересу і відсутність чутливості до теми коронавируса, мова творчості - можливо, єдиний ефективний спосіб донести важливе. Саме нестандартний погляд на звичайні речі - те, що робить художній підхід до протидії Коронавіруси помітним [1].

«Ковідне мистецтво» чи «мистецтво карантину» породило багато нових форм та проявів мистецтва, дистанцює глядачів та митців, та водночас, зближує їх засобами сучасних технологій та інтернету, художники показують нам наше майбутне та спонукають до роздумів, у якому світі, суспільстві, з якою екологією, цінностями, обмеженнями та можливостями ми хотіли б жити далі.

\title{
Література:
}

1. Как искусство рассказывает о COVID-19. [Електронний ресурс] Режім доступу до ресурсу: https://hromadske.ua/ru/posts/kak-iskusstvorasskazyvaet-o-covid-19

DOI https://doi.org/10.30525/978-9934-26-004-9-95

\section{MASTERING VOCAL-PERFORMING TECHNIQUES BY STUDENTS IN A POP SINGING CLASS}

\author{
Folomieieva N. A. \\ Candidate of Pedagogical Sciences, Associate Professor, \\ Associate Professor at the Department of Choral Conducting, \\ Vocal and Methods of Music Education \\ Sumy State Pedagogical University named after A. S. Makarenko \\ Sumy, Ukraine
}

The conditions of modern pop vocal performance and its stylistic differentiation require, in particular, the use of various vocal-performing techniques in pop singing, that's why one of the important components of the 100 
process of professional training of future pop singers is their mastery of various vocal-performing techniques. The mastery and free use of various vocal-performing techniques to a large extent ensures the competitiveness of pop singers in the current labor market.

Various aspects of vocal training were covered in the works of such authors as: H. Carter [1], K. Linklater [2], S. Riggs [3], C. Sadolin [4] and others. However, the mastering vocal-performing techniques by students in a pop singing class have not been the subject of any of the relevant studies.

It is advisable to determine the vocal-performing techniques. These are specific methods of sound production, which are used in pop performance and give the voice sensuality, expressiveness in certain parts of the song, which acquire a special «color».

One of specific to pop singing vocal-performing technique is twang - a special sound that is formed by the simultaneous closure of the soft palate and «collar» of the larynx, which provides «humming». It differs from the phenomenon of impedance substantiated in the works of R. Yusson by the place of localization in relation to the phonation organs: the impedance concerns, first of all, the oral cavity, and the twang - the larynx. «Vocal» twang can take two main forms: «pure» («oral») and nasal («nasal»), and methodically begin to master more appropriate from the nasal, as «pure» twang in an untrained singer can trigger a physiological mechanism with closure and true and false vocal cords, which can cause phonotrauma. The study of nasal twang should begin with classical vocalizations to the sounds «n» in the absence of forcing and not creating excessive pressure in the closed mouth, because the closed mouth stimulates the closure of the «collar» of the larynx.

Another vocal-performing technique is subtone (or singing with a sigh). Subtone is very similar to whispering. The sound should be soft, and your normal voice, which we use in language, should be barely audible along with the breath. Examples of this technique can be heard in jazz and pop music, such as Sade, Tony Braxton, Cher or Tanita Tikaram.

To imagine the work of the vocal folds, it is enough to imagine two sails in the wind: well stretched, but made of elastic material, between which a strong gust of wind - they meet the elastic coating, the edges, vibrate in the wind. And two sails made of absolutely elastic material, rigid, with a weak gust of wind they touch the hard edges, but the wind only slightly sways them (this is an analogy of a conversational whisper), and finally two rigid sails, which a strong gust of wind shakes, hitting one about one (this is an analogy of the subtone).

In the process of mastering the subtone vocal-performing technique, it is also important to have a high level of technique of using a microphone and interaction with the sound engineer. The use of this vocal-performing 
technique is associated with a significant reduction in the dynamic range, so without proving the automaticity of microphone skills and good coordination in working with the sound engineer, the subtone used in concert performance may not get the desired effect.

Yodel (or «tyrolean singing») consists of a sharp transition from singing «on a support» to a falsetto. Characteristic roulades, jumps at wide intervals, transitions from the thoracic low voice register to the high falsetto. This singing is mostly known in Switzerland and Austrian Tyrol.

In modern music it is widely used by such performers as Dolores O’Riordan («Cranberries»), Alanis Morissette, Gwen Stefani, Avril Lavigne, Billie Myers.

For some time, the so-called «Reverse Yodel» has become widespread, which is, as you might guess, a sharp transition from falsetto to «resistance». Examples of this technique can be found in the songs of Linda Perry (4 Non Blondes).

Strohbass (German - Strohbass, literally - «straw bass») - a type of phonation, in which the vocal cords vibrate, but almost not tense. It is the lowest vocal register, during which the production of the sound itself takes place with the help of air passing through a relaxed glottis, as if «freely oscillating». Strohbass usually sounds like a quiet, creaking voice and hardly strains the vocal cords. The name «fry» is used for the corresponding sound: strohbass reminds a sound of frying and squeaking of oil on a frying pan. The upper limit of the strohbass range coincides with the lower limit of the thoracic register (approximately «E» of the major octave). In a trained singer, the transition between the thoracic register and the strohbass may be inconspicuous. As you move down, the sound becomes less melodic, gradually turning into a creak. The lower limit of the strohbass range is almost unlimited and is determined, rather, by the limit of tone recognition in the sound.

Strohbass has long been used in academic vocals, and was later used by rock vocalists to learn to sing with a rattle. But most importantly - thanks to this vocal vocal-performing technique you can warm up the relationship without the use of chants or relax if you sang for a long time or talked a lot.

Strohbass is produced by the oscillations of false connections that are behind and in front of our vocal cords. False connections fluctuate during this exercise, and your vocal cords are relaxed.

To learn how to do shtrohbass, remember your voice right after waking up. The words sound like hoarseness, it's a strobe. This is because the body and vocal cords are as relaxed as possible. To add brightness to the sound and make it a little louder, you need to lift your nose a little and make a slight smile. Try this one the sound of «A». In the neck area around the ligament 
there may be a warm warming sensation. Now try to stretch the sound to «A» in the shtrohbass.

When you have managed to achieve a continuous rattle on the strut, try to intone with a rattle. That is to amplify and mute the sound of the voice, change its pitch.

Filleting (French filer un son - «to pull the sound») - vocal-performing technique, that change the dynamics of the sound on the sustained tone of the same pitch, for example, from $p$ to $f$ and back to $p$. Thinning is an indicator of free possession of vocal technique. Using milling, you can clearly «paint» with the sound of a voice or instrument.

Another vocal-performing technique, used in the class of pop vocal, is bending - a sound-elevating tension, an «bend» to a note, followed by fixing on the desired note. Vocal bending (sometimes referred to as «runs») is similar to an instrument that is performed on an electric guitar and usually has an improvisational nature and is limited to halftone around the note. Bending usually begins or ends with a phrase or a word. In the process of studying, it is necessary to pay attention to fixing the sound, which is preceded by a band and its functionality within a particular work, if such a fixation is not a melody mixed with the melismatics of execution, and the whole structure of the song is violated. In general, it will be much more expedient to have a few pads in the required places than a lot of padding where it is not needed. It is better for beginners to begin to work out this vocal - technical reception from the band to the tone from below to the required note, then - three half-tone steps from below to the note, at first - at a slow pace.

Another similar technique is the slide (from the english «slide»-slip), which in a classical voice statement is called "glisando», consisting of a smooth ascending or descending transition from one note to another through the reproduction of all possible vocal reproductions of sounds between them.

Other specific vocal-performing techniques are, for example, «flutter» (laryngeal singing, «rick»), «screaming» (tumultuous high cry with hoarseness), but their coverage is not the subject of this publication. In any case, the development of new vocal-performing techniques for sound production or vocal-performing techniques should take place under the supervision of a specialist and in accordance with the methodological principles of vocal training, as well as observing the rules of voice protection and periodic monitoring of the state of the voice apparatus.

Mastering vocal-performing techniques should take place at a stage when the student has fully mastered vocal breathing, the use of resonators, is able to accurately intone and fully use the main features of his voice. Mastering vocalperforming techniques in the process of professional training should take place within the disciplines «Specialty», «Pop and jazz singing». It is expedient to master the vocal-performing techniques, which are necessary for the 
performance of a song from the student's educational repertoire. At the same time, advanced mastering of other vocal-performing techniques by senior students under the condition of their vocal-performing readiness for this is also an urgent task of a teacher of pop singing of higher education institutions.

\title{
References:
}

1. Carter H. Vocal Warm-ups and Vocalises. Huntington Beach, CA.: Goldenwest College Publication, 2003. 214 p.

2. Linklater K. Freeing the Natural Voice. New York: Drama Book Specialists, 1976. 254 p.

3. Riggs S. Singing for the Stars: A Complete Program for Training Your Voice. Los Angeles, CA: Alfred Publishing Co., Inc, 1998. 168 p.

4. Sadolin C. Complete Vocal Technique. Denmark, 2000. 255 p.

DOI https://doi.org/10.30525/978-9934-26-004-9-96

\section{ПРОФЕСІЙНЕ ДЕКОРАТИВНЕ МИСТЕЦТВО УКРАЇНИ: ТЕНДЕНЦІЇ РОЗВИТКУ В УМОВАХ СВІТОВИХ ГЛОБАЛІЗАЦІЙНИХ ПРОЦЕСІВ (КЕРАМІКА, СКЛО, ДЕРЕВО, ТЕКСТИЛЬ)}

\author{
Чегусова 3. A. \\ заслужений діяч мистецтв Украӥни, \\ науковий співробітник відділу образотворчого \\ і декоративно-прикладного мистеитва \\ Інституту мистецтвознавства, фольклористики та етнології \\ імені М. Т. Рильського Начіональної академії наук Украӥни \\ м. Київ, Україна
}

У науковій доповіді розкриваються особливості розвитку професійного декоративного мистецтва України в умовах світових глобалізаційних процесів, висвітлюється його роль у формуванні такого визначного чинника як національно-культурна ідентичність українського народу у діючих парадигмах нової реальності суспільства.

Проблематика української національно-культурної ідентичності $\epsilon$ предметом дослідження числених вітчизняних вчених-гуманітарієв, 3-поміж яких В. Андрущенко, I. Бех, В. Воронкова, В. Горський, К. Журба, М. Козловець, С. Кримський, М. Михальченко, Р. Поліщук, М. Попович, М. Розумовський, Н. Скрицька, В. Табачковський, О. Титар, Д. Шевчук, В. Шейко та ін. 